\title{
The financial and economic feasibility of rural household biodigesters for poor communities in South Africa
}

\author{
Michael T. Smith*, Jessica Schroenn Goebel*, James N. Blignaut ${ }^{\star *}$ \\ *University of KwaZulu-Natal, King Edward Avenue, Scottsville, Pietermaritzburg 3201, KwaZulu-Natal, South Africa \\ ** University of Pretoria, Lynwood Road, Pretoria 0002, Gauteng, South Africa
}

\begin{abstract}
:
Given the persistence of systemic poverty in, most notably, the rural parts of South Africa, the question is whether the use of biodigesters as a source of energy offers potential solutions to some of the difficulties and development needs faced by people in these areas. At the core, this translates into whether this technology would be financially and economically feasible for installation and use by rural households. Here we conduct both a financial and an economic costbenefit analysis in one such community based on survey data from 120 households. Analysis of these data and supporting literature reveals that a biodigester is not a financially feasible investment for a rural household. Substantial economic benefits are, however, found to make a biodigester a worthwhile investment from a broader societal perspective. This is a compelling argument for further study and the consideration of government support in the light of broader economy-wide benefits.
\end{abstract}

Keywords: Biogas, biodigester, rural, poverty, energy, development.

\section{INTRODUCTION}

Austin and Blignaut (2008) was the first national-level economy-wide study to have highlighted the potential of biogas in South Africa as an alternative form of thermal energy. This study highlighted some of the social, economic and environmental benefits associated with the implementation of a rural biodigester programme in South Africa. In addition to the biodigester output benefits of biogas for cooking and fertiliser for crop cultivation, some of the benefits that were included in the economic analysis were avoiding deforestation by replacing fuelwood as a household thermal fuel; saving time by not having to collect this fuelwood; improving soil fertility by using bioslurry as a fertiliser; and reducing health-care costs as a result of replacing solid fuels and open cooking fires (which impact on indoor air quality and cause health problems) with clean burning biogas (Austin and Blignaut 2008:9).

This largely desktop analysis was followed by another qualitative description of the importance of biogas in the context of economic development (Blignaut 2009). Herein it was mentioned that a biodigester has the potential to contribute to the achievement of the United Nations' Millennium Development Goals (MDGs) numbers 1, 3, 4, 5 and 7. ${ }^{1}$

${ }^{1}$ 1. Eradicating extreme poverty and hunger, 3. Promoting gender equality and empowering women, 4 . Reducing child mortality rates, 5. Improving maternal health, 7. Ensuring environmental sustainability (UNDP, 2013). 
This research, based on Smith (2011) aims to close the gap between desktop and qualitative analysis, by investigating the actual and potential application of biodigesters to a specific rural community in South Africa. The technology considered is a prefabricated biodigester made by a South African company (AGAMA Energy). The technology is applicable for an individual rural household and the household is required to feed the digester with $20 \mathrm{~kg}$ of cow manure ${ }^{1}$ and 20 litres of water per day. As part of this study, four AGAMA BiogasPro6 digesters were installed at four separate households and the activity and impacts of the households were monitored closely. These pilot studies provided qualitative information, while a comprehensive household survey of the study community was applied for the remaining data requirements. The objective of this study, therefore, was to identify whether biodigesters installed in rural South African households were financially and economically feasible, while including some practical information from the experiences of pilot study households. The methodology used in achieving these objectives is first presented, followed by a presentation of results, a discussion of some practical experience and a conclusion.

\section{MATERIALS AND METHOD}

\subsection{Selection and description of study site}

The study area chosen for this research, the Okhombe community, is situated in the Okhahlamba Municipality, KwaZulu-Natal, South Africa (Figure 1). The community, which under apartheid South Africa was part of a non-independent homeland, is a rural one which has had limited access to development and the supply of basic services (Chellan 2002: 46). The population of the community was estimated at 6343 people from approximately 1160 households (Smith 2011: 12). The Okhombe community represents a typical rural setting that is situated 50 kilometres from the nearest town, with many households lacking adequate food, water and energy security (Sookraj 2002). There is no formal economic base providing a sustained source of income, so the community is, for the most part, dependent on income from outside the surrounding area and therefore highly vulnerable to changes in economic conditions elsewhere. It is thus one that would benefit greatly from a system that could provide an internal source of energy and a means for aiding food production, such as the use of biodigesters. The selection of the community for study was directed by these characteristics and the fact that existing and prior research in the area made the community accessible and receptive to further research. In addition, an existing project (Water Research Commission Project K5/1955) had installed four biodigesters at pilot study households in the area and was conducting research relating to all implications. The scope of the project was limited to a single community as it gave practical feasibility to conduct a comprehensive survey and cost-benefit analysis (CBA) which could reflect on similar remote and rural communities throughout KwaZulu-Natal and South Africa.

\footnotetext{
${ }^{1}$ This requires that the household own four cattle that are kraaled (kept in an enclosure) over night.
} 


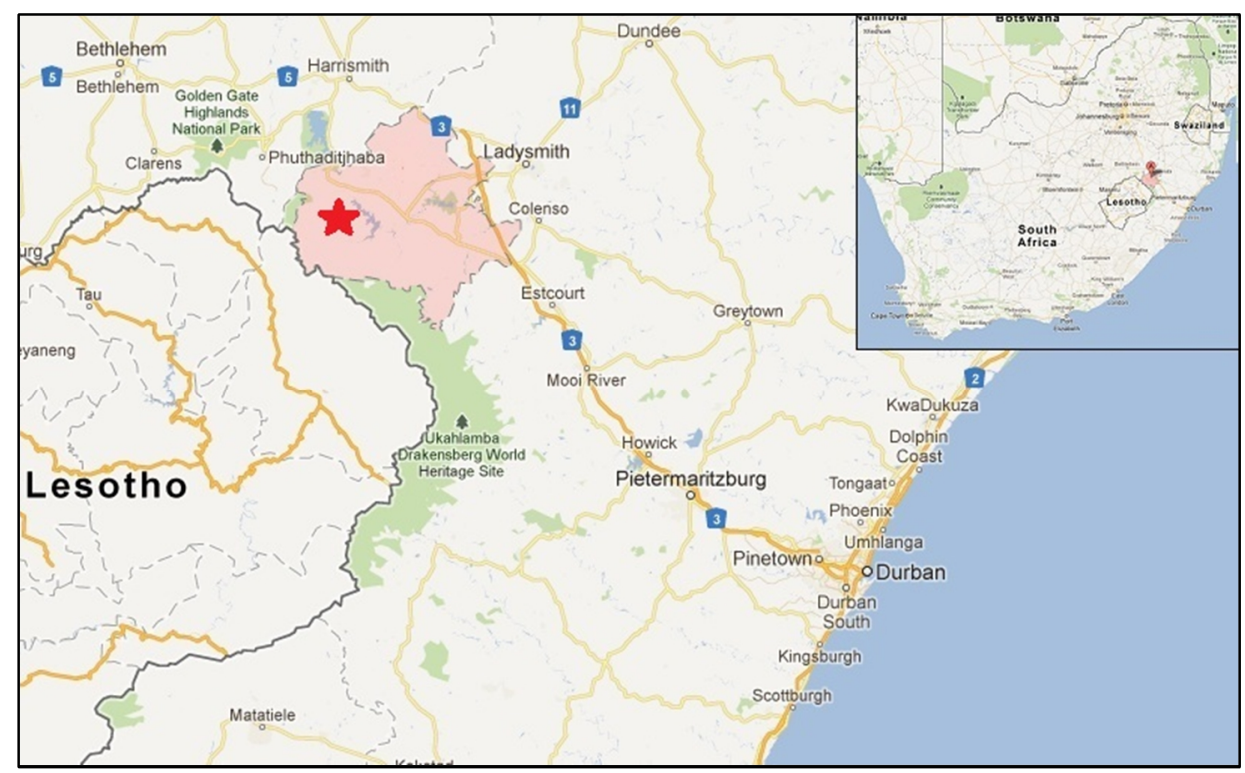

Figure 1. Map showing the location of the Okhlahamba Local Municipality (the shaded area) and the location of the Okhombe community within this municipality (approximately marked by the red star) (Google Maps 2013)

\subsection{Community survey}

This study's result is based on information obtained using a structured questionnaire. The questionnaire was based on that used by Austin and Blignaut (2008) - designed to gather detailed information about the households with respect to demography, their energy requirements, livestock keeping practices, water usage and the production of crops and vegetables at their homesteads. The interviews were conducted in isiZulu by a trained interviewer who had work experience with environmental and development non-governmental organisations (NGOs) and was familiar with the rural area, cultural intricacies and local language. The questionnaire was administered to 135 households in the Okhombe community. Houses are dispersed randomly in these rural areas, with no distinct pattern of wealth nor any registry information to guide survey selection. The surveyed households were therefore chosen specifically to cover a wide and representative sample across the study area. The interviewers informed judgement was relied upon, with a mandate given to interview a representative number of houses within each of the smaller villages (of which there are five) in the community. The households were asked 70 questions, from a questionnaire designed to illicit predominantly quantitative feedback. Fifteen of the questionnaires were disregarded due to contradictory and unreliable responses, and thus the final sample size (120 households) represented 10.2 per cent of the estimated population. Results confirmed that the sample distribution across the study area was representative and wellspread across a range of households.

\subsection{Impact quantification and appraisal of costs and benefits}

The quantitative results from the community survey were gathered and analysed using IBM's Statistical Package for Social Sciences (SPSS) and Microsoft Excel. The impacts associated with the implementation of a biodigester for rural household use are diverse and therefore required a range of methods for cost and benefit appraisal. In the subsequent analysis, 'financial' and 'economic' values (and feasibility) were distinguished. The former are direct, out-of-pocket costs 
(or savings), and are usually more readily quantifiable; the latter include broader social benefits that do not accrue directly or exclusively to the households concerned. This distinction was made in view of the fact that rural households and decision makers are arguably likely to base their investment decisions on whether a biodigester system will save them money (and possibly time), rather than on broader social (economic) costs and benefits that are more difficult to quantify and/or do not accrue directly to them, while provincial and national government stakeholders (and possibly aid organisations) are more likely to consider larger economic values.

The likely impacts of biodigester and biogas use, based on the assumption of household-sized biodigesters installed at individual homesteads in the study area, are summarised in

Table 1 (italicised items were not included in the valuation). A more detailed breakdown is included in Appendix A.

Table 1. Summary of costs and benefits relating to a biodigester installed at a rural household

\begin{tabular}{ll}
\hline Financial costs & Financial benefits \\
\hline BiogasPro digester & Avoided cooking fuel costs \\
Biodigester transportation & Avoided fertiliser costs \\
Installation costs & Avoided medical expenditure \\
Biogas-utilizing burner & Financial value of saved lives \\
Repair and maintenance & \\
Training and technical assistance & \\
\hline Economic costs & Economic benefits \\
Social costs of biodigester transport & Time saving from cooking with biogas: \\
Time spent feeding biodigester & firewood collection time; \\
& cooking and utensil-cleaning time \\
& Improved health: \\
health-related productivity gains; & saved lives \\
& Environmental benefits including: \\
& preservation of indigenous trees; \\
erosion reduction; & greenhouse gas and CO2 reduction \\
\hline
\end{tabular}

\subsubsection{Quantification of costs}

It was recognised that the capital cost of a digester and installation would likely be the greatest cost component. The biodigester used in this research was a BiogasPro made by AGAMA Energy at a retail cost of ZAR 22743.00 (US\$ 2857 at an exchange rate of US\$ $1=$ ZAR $7.96^{1}$ ). Using the BiogasPro biodigester as the only option could be regarded as a potential limitation. However, considering the possibility of a rapid and large-scale national roll-out of biogas digesters, there is a need for technological reliability and consistency. This is offered by the prefabricated technology - more so than any of the manually on-site constructed alternatives. While it is acknowledged that the pre-fabricated digester is arguably more expensive than its competitors, the demands which replication across a large area would bring have to be

\footnotetext{
${ }^{1}$ Asian Development Bank suggests using "the official exchange rate at appraisal" (ADB, 1999: 123). Exchange rates are the official rate stated by South African Reserve Bank on 11/11/2011. PPP-adjustments are made on the basis of these stated exchange rates.
} 
addressed; hence we opted to consider this technology only. While the potential benefits of economies of scale do exist, and would bring a reduction in unit cost over time, we did not consider that here so as not to create a perspective based on an uncertain future.

With regard to economic costs, the social cost of transport was taken into account and limited to the social cost of carbon (SCC) emissions. Fuel consumption ${ }^{1}$ and carbon dioxide $\left(\mathrm{CO}_{2}\right)$ emissions $^{2}$ for heavy duty vehicles (used to transport nine biodigesters at one time) was taken as an average from eight different sources. Similarly, the cost of $\mathrm{CO}_{2}$ emissions was taken as an average across values used for policy making in America, Canada and the United Kingdom (Ackerman and Stanton 2010; DECC 2011b; Gregory 2011).

The cost of time taken to manage and run a biodigester was also taken into account as an economic cost. The average time taken to collect dung and water was calculated from surveyed responses, and the time taken to 'feed' the digester was assumed to be 10 minutes per day, based on comparable experience. The net time saving was calculated and valued as per Section 2.3.2.1.

\subsubsection{Quantification of benefits}

Financial and economic benefits that would accrue to the household and society as a whole were distinguished. Avoided expenditures on cooking fuels and chemical fertilisers were classified as financial benefits. Time saving as a result of redundant wood collection and cooking practices was identified as an economic benefit. Reduced indoor air pollution was recognised to have health benefits and a reduction in the loss of life, which have both financial and economic implications. The following discussion reveals some of the methods used in quantifying and assigning value to these benefits.

\subsubsection{The value of time}

The use of a biodigester at household level requires users to spend time feeding the system, but it also considerably reduces the need for rural people to collect wood and saves time in traditional cooking practices with solid fuels. On the assumption that a biodigester system may result in a net time saving (or loss), then it is necessary to assign the value of that time as an economic benefit (or cost). Although there is much debate and apparently many differing methods of measuring the non-market value of time, the opportunity cost is the most commonly used means of valuing time (Edwards 2008:22).

In rural scenarios with high unemployment levels, such as that of the Okhombe community, the best alternative for time is arguably to be working and earning an income from that work. Although there is much debate, the Asian Development Bank (1999), along with numerous other publications, propose that the value of time should be "calculated on the basis of local minimum wage rate for unskilled labour" (Asian Development Bank 1999:149; Austin and Blignaut 2008:29; World Bank 1996:39).

In most rural scenarios it is empirically improbable that extra time available in a day (or lost in a day) would always be directly used for income-generating economic activity. Again, there is much debate, among the advocates of using a shadow wage, about the appropriate weighting for accurate appraisal of the opportunity cost of time in rural areas. The method used by the World

\footnotetext{
${ }^{1}$ Millikin 2009; US Department of Energy 2005; Franzese et al 2009; Lowell and Balon 2009.

${ }^{2}$ Davies 2004; Comcar 2011; EPA 2005; Healey 2003.
} 
Bank (1996) in a study on rural water supply and sanitation in Nepal, was considered to be most appropriate for application to this research.

The World Bank (1996:39) considered time to be a weighted value of the unskilled labour wage rate where:

- Productive economic activity is taken as $100 \%$ of the unskilled labour wage rate

- Household activity is taken as $50 \%$ of the unskilled labour wage rate

- Other activity (including leisure and socialising) is taken as $25 \%$ of the unskilled labour wage rate.

The household questionnaire asked respondents how they would be most likely to spend any time potentially freed up by the use of biogas instead of traditional, more time-consuming cooking methods. An equation was used to calculate the weighted opportunity cost of one hour in the Okhombe community, based on the frequency of the various responses. The potential activities are denoted by $e$ (economic activity), $h$ (household activity), $s$ (social activity); and each is multiplied by a weighted minimum wage rate $(w-$ calculated as the average minimum wage rate for unskilled labour in South Africa) (Equation 1).

Equation 1:

$$
V_{t}=e(1 \cdot w)+h(0.5 \cdot w)+s(0.25 \cdot w)
$$

Where:

$V_{t}$ is the economic value of time (ZAR/ hour)

e is the percentage of people who will seek or partake in economic activity (\%)

$w$ is the minimum wage rate for unskilled labour (ZAR)

$h$ is the percentage of people who will use time for household activities (\%)

$s$ is the percentage of people who will spend time on other activities (\%)

Once the weighted hourly opportunity cost of time was calculated, the average time saving and cost (as calculated from a compilation of analysed questionnaire data and pre-existing studies) could be multiplied by this weighted value of time.

\subsubsection{The valuation of output benefits}

The output benefits of a biodigester are biogas, which can be used for cooking, and bioslurry (liquid digested effluent), which is considered a good replacement for chemical fertilisers and a high quality fertiliser for rural agriculture (Pandey et al. 2005:3; Khan and Khan 2009:468). These outputs have potential to contribute to making a biodigester a financially attractive investment for rural households and are thus valued at a household level by considering the costs 
of energy and fertiliser that may be replaced, and therefore avoided.

The calculation of avoided fertiliser costs was easily attainable. Questionnaire data provided information regarding the quantity used and cost of fertiliser for the average household in Okhombe. Based on the quantity of cow manure and water being fed into a biodigester daily (20 litre of water and $20 \mathrm{~kg}$ of cow manure), it was clear that there would be an abundant supply of bioslurry to replace purchased chemical fertilisers. The financial saving was thus calculated as the avoided average cost of fertiliser per household. It could be argued, however, that the economic benefit of an extra quantity of bioslurry further augments the value of this output.

The quantification of avoided energy costs (the financial value of biogas) was a more convoluted process considering the survey finding that a wide variety of fuels are used for cooking in rural households. The assumption was made that the produced biogas would be sufficient to cater for all the households cooking needs, and would therefore replace all energies and fuels used for cooking ${ }^{1}$. Fuelwood, paraffin (kerosene), electricity, liquid petroleum gas (LPG) and dried cow dung were identified as fuels used by households, with most households using a variety of these energy sources. The household questionnaire asked households to rank their use of each energy source as primary (used most often), secondary or tertiary fuel.

Fuelwood usage, and purchase, was conservatively assumed to be reduced by $65 \%$, as fuelwood is used for purposes other than cooking (thermal heating for example). Paraffin was used as a primary, secondary and tertiary form of cooking in various households and for this reason a weighted calculation was used to determine the aggregate avoided cost of paraffin used for cooking purposes. The quantity of paraffin used for cooking (10.2 litres per month $)^{2}$ by the average rural household that uses paraffin as its primary source of cooking was extrapolated from an existing study that surveyed 18 rural communities throughout South Africa (Paulsen et al. 2010: 28). The average paraffin usage for cooking in Okhombe was weighted by assuming that primary users would replace $100 \%$ of this amount, secondary users would replace $50 \%$ and tertiary users would replace $12.5 \%$ (Equation 2).

Equation 2:

$$
C_{p}=p_{p}\left[\left(\frac{H_{p}\left(100 \% \times q_{p}\right)+H_{s}\left(50 \% \times q_{p}\right)+H_{t}\left(12.5 \% \times q_{p}\right)}{120}\right)\right]
$$

Where

$C_{p}$ is the average amount spent on purchased paraffin (ZAR/month)

$p_{p}$ is the price of paraffin (ZAR/litre)

$H_{p}$ is the number of households that use paraffin as their primary energy source for cooking

\footnotetext{
${ }^{1}$ The average rural household of the sample group (Okhombe) was found to have 5.39 inhabitants. Austin and Blignaut (2008: 21) found that a $6 \mathrm{~m}^{3}$ digester (similar to the size of the BiogasPro) was sufficient for the cooking and lighting needs of a 4-5 people household. It is not being suggested that lighting be replaced in this study and therefore a digester fed with $20 \mathrm{~kg}$ of cow manure and 20 litres of water was assumed to provide sufficient gas to cater for all cooking energy requirements.

${ }^{2}$ Paulsen et al. found that on average, rural households in their study sample used 5.1 litres of paraffin per week (20.4 litres per month) (Paulsen et al., 2010: 28). It is assumed in this study that only 50\% of this quantity (10.2 litres per month) is used for cooking.
} 


\section{$H_{s}$ is the number of households that use paraffin as their secondary energy source for cooking}

$H_{t}$ is the number of households that use paraffin as their tertiary energy source for cooking.

$q_{p}$ is the quantity of paraffin used by the average household for cooking, as extrapolated from the Paulsen et al. (10.2 litres/month).

Similarly to fuelwood, it was discovered that liquid petroleum gas (LPG) and electricity were used for a variety of activities in the study area and that biogas would only replace cooking needs ${ }^{1}$. With reference to LPG, some households used the energy for heating, refrigeration and cooking. In order to disaggregate the use of cooking from other activities, the quantities stated by those who only used LPG for cooking purposes ${ }^{2}$ (51\% of LPG users) were calculated first. Once the average quantity of gas used by households who only cooked with LPG was calculated, this average was used for all LPG using households who cooked with LPG and used it for other purposes.

It was also necessary to disaggregate the expenditure on electricity used for cooking. The survey results displayed that all electrified households used electricity for lighting, with $80 \%$ using it for cooking and $27.5 \%$ using it for heating. The method used in disaggregating LPG usage could not be utilised here as no households used electricity solely for cooking. However, because $15 \%$ of households used electricity solely for lighting, it was possible to calculate an average expenditure on lighting. This was deducted from the average total electricity expenditure of households who both cooked and illuminated with electricity (55\% of households), to arrive at an average expenditure on electricity for cooking purposes, which was in turn applied to all households who cooked with electricity ${ }^{3}$. This approach was used with confidence as there was a clear difference in electricity expenditure for households who used electricity for one, two or three purposes.

Each of the avoided energy costs on various fuels was calculated as an aggregate across the entire sample size (120 households) and on that account it was possible to compile them, calculating an aggregate avoided fuel cost per household in Okhombe.

\subsubsection{The economic value of human life}

Indoor air pollution (IAP) is considered not only to be a high risk factor in the cases of related disease, but also in subsequent death. The reduction in lives lost due to reduced incidence of IAP related disease has financial and economic implications (Renwick et al. 2007:33).

The economic valuation of human life is a highly contentious debate. Although there is considerable ethical and moral opposition to the idea of attempting to value human life, Schelling (1968: cited in Brent 2006) gives wise perspective to the economist's predicament. Schelling argued that, when valuing death (or life), it is statistical death that is being valued and not certain death, for which value would certainly be infinite (Brent 2006:191). A CBA evaluator is tasked

\footnotetext{
${ }^{1}$ It is noted that biogas has potential to replace lighting and other energy requirements; however, cooking was chosen as the only affected activity for the purpose of this research.

${ }^{2}$ This includes households who used LPG for water heating purposes. Water heating is an activity that can be replaced by biogas use.

${ }^{3}$ Including those households who also heated with electricity.
} 
with allocating scarce resources, and is required to assess costs and benefits for an array of different possibilities; it is imperative that the economic value of human life be recognised in these assessments. The evaluator is thus faced with little choice other than to place an economic value on human life (Brent 2006:191).

The total number of IAP related deaths in the study area was calculated using environmental health burden of disease data from the World Health Organization (WHO 2004; WHO 2007). Indoor air pollution is considered to be a result of solid fuel use in households and thus, all IAP related deaths were considered to be from only those households that used solid fuels as an energy source (17.3\% of the South African population) (WHO 2007). Using the death statistics from the World Health Organization, it was possible to calculate the number of IAP related deaths per 100 solid fuel users, per year in South Africa. Once this figure was calculated, it was possible to determine the number of deaths per year in the study area that would be as a result of IAP.

It was assumed that only households that cooked with solid fuels would benefit from a reduction in $\mathrm{IAP}^{1}$ and thus the calculation of IAP related deaths for the study area was based on the number of households that used fuelwood, cow dung or coal as their primary and/or secondary cooking fuel. It was assumed that the use of biogas will reduce $65 \%$ of IAP, on the basis that the use of biogas reduces fuelwood consumption by $65 \%$, and consequently that $65 \%$ of potential IAP related deaths will be reduced by the use of biogas in place of traditional solid fuels.

In consideration of the financial benefits of avoided lives lost, future income and avoided cost of death are relevant. Due to the high unemployment rates and the fact that women and children, who are most likely to be affected by IAP related diseases (Legros et al. 2009:22; Banik 2010:210) are often not in income earning positions in rural areas, it is commonplace to consider the cost of death and not loss of future income in these settings (Renwick et al. 2007:34). The cost of death was valued at the cost of an average funeral in rural areas of South Africa.

In assessing the economic impact of potentially avoided mortality, the value of a statistical life (VOSL) is used. A value of US\$ 9.1 million (2011 US\$) is used by the Environmental Protection Agency (EPA) of the United States of America and appears to be the most widely recognised value, with considerable attempts made by the EPA to use scientifically sound methods of calculation (Sinha et al. 2010²:121; Appelbaum 2011). The value used by the EPA is, however, calculated with respect to the labour markets of a first world developed country. Value of statistical life studies relating to developing and emerging economic countries are very rare, and thus it was decided to use a conservative mean estimate of US\$ 2 million as used by Renwick et al. (2007:34), who extrapolate estimates made for North America and Western European countries for the Sub-Saharan African context. Similarly to Renwick et al. (2007:34) we use purchasing power parity (PPP) to convert the US\$ 2 million into 2011 ZAR, so as to reflect the actual worth of the money in the South African context.

\subsection{Cost-benefit analysis}

The nature of this research and of rural development projects in general is characterised by a diverse range of potential implications. Sustainable development, in the context of the key ingredients referred to previously, is especially denoted by the need for comprehensive appraisal

\footnotetext{
${ }^{1}$ Biogas will only replace cooking fuels.

${ }^{2}$ This report was published in 2010 and the VOSL was still used in 2011 as US\$ 9.1 million.
} 
of financial, environmental, economic and social consequences. The versatility of CBA was required, and a clear distinction was drawn between the financial and economic appraisals. The financial and economic findings were segregated in recognition of the fact that rural households and decision makers are arguably likely to base their investment decisions on whether a biodigester system will save them money (and possibly time), rather than on broader social (economic) costs and benefits that do not accrue directly to them.

Standard CBA principles were used to conduct the appraisal and impacts were discounted at a rate of $6 \%$, based on the consultation of a variety of literature (Mullins et al. 2007; Stats SA 2011; European Commission 2006). This discount rate is deemed appropriate from an investment perspective, either by the government or the private sector, which by and large take a long term view on development. Within a developing context characterised by deep-seated systemically engrained poverty the focus is much more short-term orientated. To accommodate this perspective we also include an analysis based on a $12 \%$ discount rate in the form of a sensitivity analysis.

The method of sensitivity analysis used in this research project and as used by Florio et al. (2008), Renwick et al. (2007) and proposed by Pearce et al. (2006), is a process by which an upper and a lower estimate is given to a range of variables in the cost benefit appraisal. The upper and lower, or optimistic and conservative, values were assigned to all uncertain variables and the net present value (NPV), internal rate of return (IRR) and benefit-cost ratio (BCR) were recalculated (Florio et al. 2008:61).

\section{RESULTS AND DISCUSSION}

\subsection{Site description and household energy use profile}

The Okhombe community is unmistakably a poor and rural community with people relying largely on subsistence agriculture and government welfare grants. The relatively low standard of living is evident in their energy use profile and the absence of basic amenities like electricity, water and indoor lavatories (pers. obsv. 2012) (see Figure 2). 

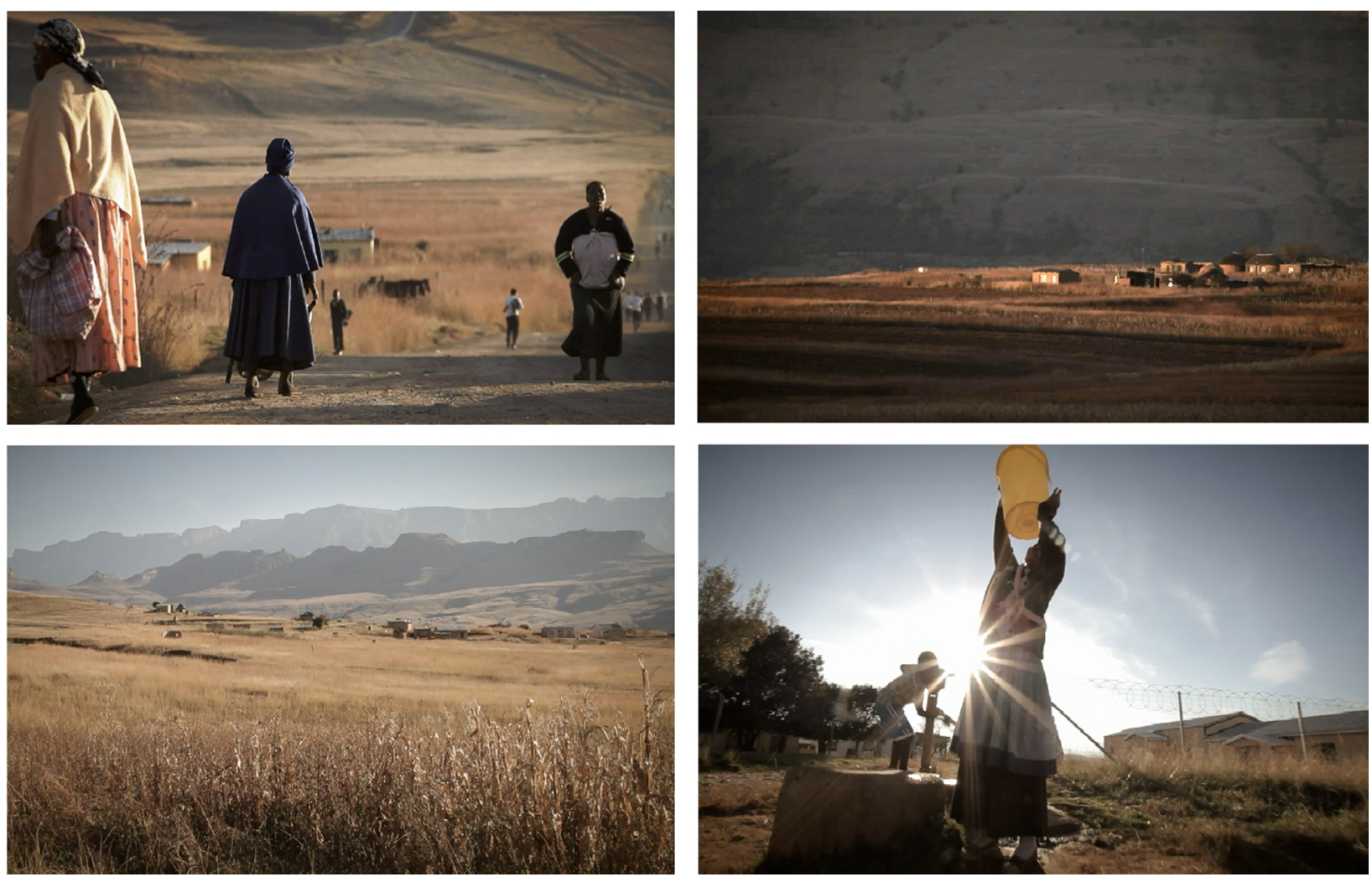

Figure 2. Images taken in the Okhombe community

Table 2 shows household size and income levels in for the survey sample. The average household size of the sample population was 5.39 people, which correlated closely with a figure of 5.47 people per household stated by Statistics South Africa for the local municipality of which the study area is a part (StatsSA 1996). The average stated household income was ZAR 1089.63 per month, with 33\% of the sample population earning ZAR 1001 to ZAR 1500 per month. The average monthly per capita income was ZAR 202.10 - substantially below the ZAR 235.00 poverty line used by the South African government as an indicator of relative poverty in 2009 (The Presidency, 2009). All of the valid interviewees were Black Africans who spoke isiZulu as their home language.

Table 2. Household size and income in Okhombe

\begin{tabular}{lc}
\hline & Household size [people] \\
\hline Minimum & 1 \\
Maximum & 14 \\
Average & 5.39 \\
\hline & Household income per month [ZAR] \\
\hline Minimum & 25.00 \\
Maximum & 7000.00 \\
Average & 1089.63 \\
Average per capita & 202.10 \\
\hline
\end{tabular}

Survey results showed that $66.6 \%$ of the households in the sample group were electrified with no 
distinction between quantity of electricity used in summer and winter months ${ }^{1}$. Fuelwood was the most widely used form of energy with $90.0 \%{ }^{2}$ of households making use of it for cooking. Fuelwood was the most commonly used primary energy for cooking $(47.5 \%)$, paraffin was second $(25.8 \%)$ and electricity was third $(21.7 \%)$. The most commonly used secondary energy form was paraffin (40.8\%) and dung was used by $52.5 \%$ of households as a tertiary source of energy. The results of these findings are displayed in Error! Reference source not found.Figure 3.

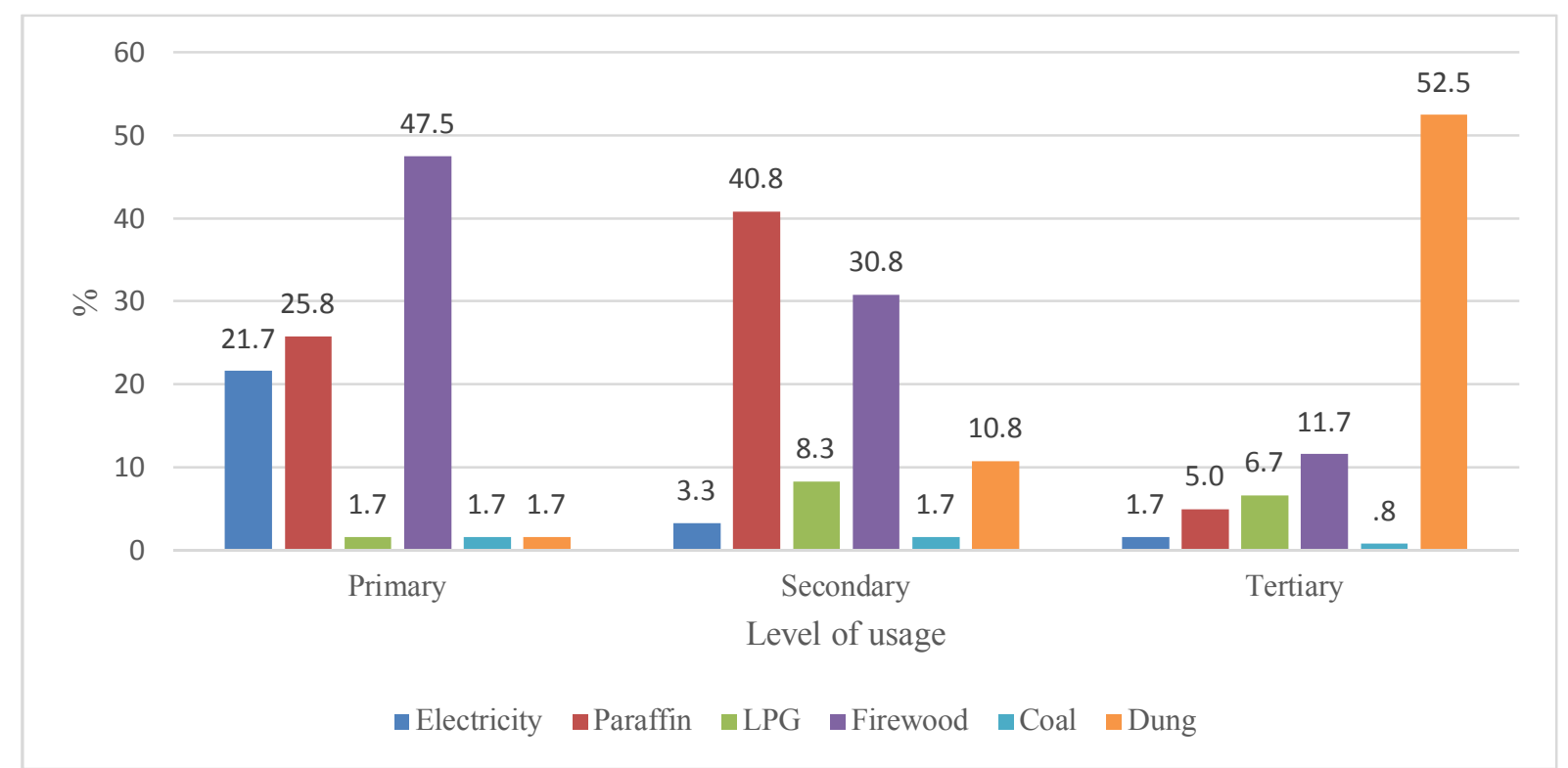

Figure 3. Percentage of households using different energy forms for cooking ${ }^{3}$

Note: Ranking was used where households used a variety of energy fuels. The rankings are primary (most used), secondary (second most used) and tertiary (third most used) energy sources.

\subsection{Cost-benefit analysis}

Following the identification and quantification of the costs and benefits likely to arise from biodigester use, a cost-benefit analysis was conducted under a base case scenario using the BiogasPro as the digester, a discount rate of $6 \%$ and a lifetime evaluation period of 15 years. Appendix A (Table 7) shows the estimated values for the components of each category of benefit or cost; totals are reflected in Table 3.

\footnotetext{
${ }^{1}$ Although counter-intuitive, this finding does not come as a surprise as only $8.33 \%$ of households used electricity as a primary space heating source and even then electricity spend is largely governed by affordance restrictions. ${ }^{2}$ Across all levels (primary, secondary and tertiary.

${ }^{3}$ Note: Ranking was used where households used a variety of energy fuels. The rankings are primary (most used), secondary (second most used) and tertiary (third most used) energy sources.
} 
Table 3. Results of the cost-benefit analysis under the base case scenario

\begin{tabular}{llll}
\hline \multicolumn{2}{c}{ Financial } & \multicolumn{2}{c}{ Economic } \\
\hline Total financial cost & ZAR 38 532.23 & Total economic cost & ZAR 46 704.43 \\
Total financial benefit & ZAR 37 880.37 & Total economic benefit & ZAR 225 487.72 \\
\hline \multicolumn{1}{c}{ Financial } & Feasibility indicators & Economic \\
\hline Financial NPV & - ZAR 651.85 & Economic NPV & ZAR 178 783.29 \\
Financial IRR & $-0.25 \%$ & Economic IRR & $57.68 \%$ \\
Financial B/C ratio & 0.98 & Economic B/C ratio & 4.83 \\
\hline
\end{tabular}

Under these assumptions, consolidated results revealed that a biodigester serving an individual household installed in the Okhombe community is, by a relatively small margin, not a financially feasible investment. The financial net present value (NPV) per household is negative ZAR 651.85 , the financial benefit cost ratio (BCR) is 0.98 and the financial internal rate of return (IRR) is negative $0.25 \%$. The greatest financial cost is the BiogasPro biodigester which represents $59.0 \%$ of all financial costs, with the cost of installation contributing a further $28.5 \%$. The most significant financial benefit is avoided fuel costs which represents $86.2 \%$ of total financial benefits. It could be postulated that this small shortfall would be recovered by a reduction in the unit cost of the digester under a large-scale roll-out plan, but any such calculation would be based on speculation and is hence excluded.

The small margin by which the project is not financially feasible is highlighted when considering the sensitivity analysis when a variation in the cost and the benefits of $20 \%$ to either side is introduced. While the pessimistic case becomes even less feasible, the project is financially viable under optimistic conditions.

Table 4. Summary of combined sensitivity analysis

\begin{tabular}{|c|c|c|c|}
\hline \multicolumn{4}{|c|}{ Combined Sensitivity Analysis (20.0\% variation) (Financial) } \\
\hline & NPV & BCR & IRR \\
\hline Conservative & -ZAR 16955.05 & 0.63 & $-6.19 \%$ \\
\hline Base & -ZAR 652 & 0.98 & $-0.25 \%$ \\
\hline Optimistic & ZAR 14630.67 & 1.47 & $6.42 \%$ \\
\hline \multicolumn{4}{|c|}{ Combined Sensitivity Analysis (20.0\% Variation) (Economic) } \\
\hline & NPV & BCR & IRR \\
\hline Conservative & ZAR 112378.84 & 3.03 & $32.07 \%$ \\
\hline Base & ZAR 178783 & 4.83 & $57.68 \%$ \\
\hline Optimistic & ZAR 233221.72 & 7.24 & $99.84 \%$ \\
\hline
\end{tabular}

In addition to the combined sensitivity analysis, another test was run where the discount rate was increased to $12 \%$ in recognition of the comments made in Section 2.4. This change does, however, indeed change the financial viability considerably, by reducing the financial IRR to negative $6.29 \%$. In the event that a household's planning horizon is less than 15 years, and the discount rate is altered to factor this into the calculations, the investment is likely to be 
financially viable only in rare cases.

In contrast to the financial outcomes, it was resoundingly clear from the economic CBA that a household biodigester installed in the Okhombe community would be an economically beneficial investment. Under the base case scenario for Okhombe, with the use of a BiogasPro as the digester and a discount rate of six per cent; the economic NPV is ZAR 178783.29 , the economic BCR is 4.83 and the economic IRR is $57.68 \%$. With regard to the economic costs, the biodigester is the greatest component at $48.7 \%$ of total economic cost. The substantial economic benefits were driven up considerably by the value of saved lives which represented $65.8 \%$ of the total economic benefit. The next highest contributor was the economic value of time saving related to biogas use and the benefit of avoided fuel costs; $17.0 \%$ and $14.5 \%$ of total economic benefit respectively.

Sensitivity analysis reinforced the economic findings and even in the scenario where the value of saved lives (the greatest contributor to economic benefit) was considered to be zero, economic feasibility indicators remained positive. Under a zero VOSL assumption, the BCR and IRR remained positive with values of 1.65 and $11.19 \%$ respectively - still strong evidence of economic feasibility (see Table 4).

\section{A BIODIGESTER AS A HOUSEHOLD INVESTMENT}

Based on the findings of the CBA, the BiogasPro digester (at current price) is not a financially feasible investment for a rural household, especially under conditions that merit the use of a high discount rate. Further to this, the direct financial benefits accruing to user households are exaggerated in the finding of a financial IRR of $-0.25 \%$, since avoided medical costs should arguably be considered a benefit to society (a reduction in government health care costs) and not a financial benefit to the household itself, given that the population in question would use South Africa's public health facilities. If these benefits are removed from the analysis of household financial benefits, the financial IRR is $-0.84 \%$.

Although a substantial economic IRR represents a desirable investment in terms of social welfare benefits, it is unlikely that a rural household would invest in a biodigester and suffer a potential financial loss. Even considering the potential health-benefiting and time-saving implications of a biodigester, it remains unlikely that a household would make this investment. Based on a loan at current South African prime interest rate of $9.0 \%$, a zero per cent deposit and various payback periods expressed in Table 5, it is clear that even over a 15 year repayment period the nominal monthly instalments would be well in excess of an average household's nominal potential monthly savings of ZAR $211.39^{1}$ (saving on avoided fuel and fertiliser costs ${ }^{2}$ ). Depending on the repayment period, the monthly repayments would amount to between $36 \%$ and $73 \%$ of average monthly household income of R1 089.63 (Table 2), which would have a huge impact on livelihoods.

\footnotetext{
${ }^{1}$ The value of life is also omitted from this discussion for logical reasons. It is expected that the value of life as a probability of death and expenditure on funeral costs would be difficult to explain to rural households.

${ }^{2}$ This value is an undiscounted value and represents average household expenditure on cooking energy.
} 
Table 5. Monthly repayments in ZAR.

\begin{tabular}{crr}
\hline Terms in months & \multicolumn{1}{c}{ Monthly repayment } & \multicolumn{1}{c}{ Total repayment } \\
\hline $\mathbf{6 0}$ & ZAR 799.87 & ZAR 47 991.94 \\
$\mathbf{1 2 0}$ & ZAR 488.11 & ZAR 58 573.20 \\
$\mathbf{1 8 0}$ & ZAR 390.82 & ZAR 70 347.52 \\
\hline
\end{tabular}

Capital investment of ZAR 38532.23

Interest rate of $9.0 \%$

The case for government and/or donor support is compelling given the significant economic and societal welfare benefits of biodigester use shown by the economic results. It is proposed that government investment, at least to a point where financial desirability becomes evident, would be worthy of consideration. Financial desirability from a household perspective would occur where the value of monthly benefits exceeds the monthly repayment on a loan. It is noted that nominal savings are in fact likely to increase in excess of inflation over the 15 year period ${ }^{1}$ given expected upward price trends of fuel, while nominal repayments are expected to remain constant, assuming a fixed interest rate. For our purposes here the nominal values of both amounts are assumed not to change.

Given a nominal borrowing rate of $9 \%$, repayment over 180 months, and a capital investment of R38 532.23, calculations reveal that a capital subsidy of ZAR 17691.00 would be the minimum required in order to equalise monthly savings (ZAR 211.39) and repayments and thus make a biodigester financially feasible for the average household in Okhombe. Table 6 displays the effect of various subsidy levels on the monthly repayment that would still be required from a household in Okhombe.

Table 6. Effects of various government subsidies on monthly repayments

\begin{tabular}{cc}
\hline Subsidy amount [ZAR] & Monthly repayment [ZAR] \\
\hline 10000.00 & 289.39 \\
17691.00 & 211.39 \\
20000.00 & 187.97 \\
\hline
\end{tabular}

Based on the information provided in Table 6, the recommendation for a subsidy of ZAR 20000.00 is made. A subsidy of this amount would provide a financial incentive for the average household to invest in a biodigester system repaid over a period of 15 years (180 months). A household's investment in a biodigester system would consequently secure the societal welfare gains inherent in the substantial economic benefit. At an interest rate of $9.0 \%$, the repayment of this investment would be ZAR 187.97 per month, which is less than the monthly monetary saving in avoided fuel and fertiliser costs, and would thus be a desirable investment.

\section{A BIODIGESTER PROGRAMME AS A MEANS OF DEVELOPMENT}

There is ample literature in support of a well-managed biodigester programme as a suitable means of tackling some of the difficulties faced by poor and rural communities. In addition to the

\footnotetext{
${ }^{1}$ The lifespan of the BiogasPro is expected to be well in excess of 15 years, however, this assessment period is used conservatively as no proof of this expected longevity exists.
} 
surveys conducted in the Okhombe community, four biodigesters were installed within the greater community to observe and corroborate the CBA and supporting literature. The BiogasPro biodigesters were installed at no cost to households chosen for the pilot study through a community selection process. Although the experience of the pilot studies was not a direct contributor to the CBA model used in this research, constant community monitoring and unobtrusive site visits were conducted to authenticate desktop research findings. To date, the pilot households have revealed an observed potential for biodigesters to meet some of the development needs of rural communities in South Africa and to contribute to the achievement of a number of Millennium Development Goals (MDG).

As found in the community surveys, the pilot households predominantly rely on fuelwood for cooking, regardless of the fact that three of the four households are electrified. Due to a lack of local timber, the majority of these households buy wood at a cost of between ZAR 500 and ZAR 900 per 'bakkie'" load, which lasts between one and three months. One of the pilot study households, who were unable to afford bought fuelwood, reported that they spend between three and four days a week collecting fuelwood approximately two kilometres from the household. As substantiated by the survey process, it appeared that women and children were predominantly responsible for wood collection and cooking practices.

Evidence from the monitoring process and expression by each of the households that they had not run out of biogas during a day's cooking suggests that the biodigesters are not yet being used to their full capacity. Regardless of this, each of the households reported that their lives have been markedly changed. All pilot study households reported that their monthly expenses on fuelwood and electricity have been dramatically reduced. In addition to these observations, one of the households that collected wood noted that they no longer needed to collect wood at all, while the other had greatly reduced the number of days spent collecting wood. In addition to saving on fuelwood purchases and reduced wood collection time, households identified that they no longer needed to constantly manage cooking fires and that they were saving time as they were simply able to turn the gas on, light it and begin cooking without the need to watch over the process. Time saving, as a result of more efficient cooking practices and reduced wood collection, reveals that a biodigester could contribute to "promoting gender equality and empowerment of women" (MDG 3) as women are relieved of time-consuming domestic duties, while efficient cooking fuel and reduced wood harvesting also have the potential to "ensure environmental sustainability" (MDG 7).

The observations from these four households corroborate many of the benefits stated in literature and display great potential to assist in the achievement of many MDGs. The observations clarified that a biodigester would assist greatly in reducing monthly expenditure on cooking fuels while providing sufficient gas for cooking and fertiliser for cultivation of food crops, thereby helping to "eradicate extreme poverty and hunger" (MDG 1). Survey findings that women and children are predominantly involved in cooking practices were confirmed by the case study households, and all households noted a great improvement in air quality after switching from indoor air polluting traditional fuels to the clean burning biogas, which reflects the ability of a biodigester to contribute to MDGs 4 and 5 ("reduce child mortality" and "improve maternal health" respectively).

The households' expenditure changes are still being monitored; however, initial observations

\footnotetext{
${ }^{1}$ A medium sized pick-up truck.
} 
provide compelling evidence that biodigesters are saving the pilot study households money. While the figures speak volumes for the potential of biodigesters to make a tangible difference to rural people's lives and contribute to the achievement of the MDGs, the response from the people involved in the households revealed more. During site visits, project members witnessed elated household members whose excitement for what they refer to as, "this miracle gas", has spread to neighbours and community members alike who are desperate to become involved with the project and have a biodigester installed in their households.

The potential for financial savings is quite evident from initial reports, but the observed ability of biodigesters to change the way rural people live their lives is even more convincing.

\section{CONCLUSION}

In conclusion, the findings of this research point strongly to the significant potential of a biodigester as a tool for sustainable development by enhancing basic living standards and quality of life in the poor rural areas of South Africa.

A household questionnaire was designed and interviews were conducted in the study area producing a valid sample size of 120 households, representing approximately $10.2 \%$ of the study area population. Methodology, informed by the literature review, was applied to the study and the financial and economic impacts of biodigester installation in a rural household in Okhombe were quantified and valued. Where current study data was not available, existing study findings were weighted and extrapolated to the current case. A comprehensive cost-benefit analysis and sensitivity analysis were carried out relating to community specific characteristics of energy usage and farming practice.

The study reveals that further academic investigation would be of great value to future project appraisals relating to biodigester use in rural communities. Specifically, further studies relating to local and global environmental benefits, as well as the potential for increased biodigester unit production and installation to give rise to economies of scale would be of particular value. Further, it is also recommended that research be directed toward the consideration of alternative technologies which could decrease capital cost and thus reduce the need for financial support.

Observation of the pilot study households provided convincing evidence that a biodigester (and related outputs) has potential to reduce monthly energy expenditure and make a tangible difference to the living standards of rural households. Findings from both survey analysis and actual observation present a strong case for biodigesters to contribute to the attainment of a number of Millennium Development Goals, with specific potential to contribute to MDG 1 ("eradicate extreme poverty and hunger"), MDG 4 and 5 ("improve the health of children and maternal women") and MDG 3 ("promote gender equality and empower women"). With reference to the key ingredients of a sustainable development package noted previously, it is clear that a biodigester's outputs have much potential to assist in both natural resource management and the provision and security of food and energy.

The final results revealed that a BiogasPro household biodigester, installed in the Okhombe community, is not a financially feasible investment. For financial feasibility to be achieved, it was concluded that significant capital cost reductions would be required.

While the results indicate non-feasibility with respect to financial outcomes, it was 
resoundingly clear that a small-scale biodigester, installed at an individual household in the Okhombe community, would be an economically beneficial investment. Significant economic feasibility was identified and this provides a convincing argument for the social value of biodigester systems in rural households. Considering a governmental imperative to uplift the social wellbeing of its people, the economic result is compelling evidence for government or donor support to make financial desirability of biodigester systems a reality.

\section{ACKNOWLEDGEMENTS}

The Authors wish to thank the Water Research Commission (WRC Project K5/1955) and South African National Research Foundation (NRF - Freestanding Masters Scholarship programme) for funding the project that made this research possible. The Authors also extend their thanks to the WRC K5/1955 Project team and especially the project leader Dr Terry Everson from the University of KwaZulu-Natal.

\section{REFERENCES}

Ackerman F. and Stanton E. (2010). The Social Cost of Carbon. Economics for Equity and Environment: Portland.

Appelbaum B. (2011). As U.S. Agencies Put More Value on Life, Businesses Fret. [The New York Times]. Available at: [http://www.nytimes.com/2011/02/17/business/economy/17regulation.html?_r=1\&scp=1\&s $\mathrm{q}=$ value $\% 20$ life \&st $=$ cse] (Accessed 19 November 2011).

Asian Development Bank (ADB). (1999). Handbook for the Economic Analysis of Water Supply Projects. ADB: Mandaluyong City.

Austin G. and Blignaut J.N. (2008). South African National Rural Domestic Biogas Feasibility assessment: Prepared for Ministry for Development Co-operation, The State of Netherlands. AGAMA Energy: Cape Town.

Banik B.K. (2010). Female perceptions on health hazards associated with indoor air pollution in Bangladesh. International Journal of Sociology and Anthropology. 2(9) 206-212.

Blignaut J.N. and van der Elst L. (2009). South Africa and Sustainable development: a reflection. Perspectives: Political analysis and commentary from Southern Africa. 3: 13-18.

Brent R.J. (2006). Applied Cost-Benefit Analysis. (2 ${ }^{\text {nd }}$ Edition). Edward Elgar Publishing Limited: Cheltenham.

Chellan N. (2002). An assessment of tourism potential in the Okhombe area, KwaZulu-Natal. Master of Arts Thesis. University of KwaZulu-Natal South Africa.

Comcar. (2011). Kg CO2 per litre. [Comcar]. Available at: [http://www.comcar.co.uk/newcar/companycar/poolresults/co2litre.cfm] (Accessed 11 November 2011). 
Davies T. (2004). Calculation of $\mathrm{CO} 2$ emissions. [University of Exeter]. Available at: [http://people.exeter.ac.uk/TWDavies/energy_conversion/Calculation $\% 20 \mathrm{of} \% 20 \mathrm{CO} \% 20 \mathrm{em}$ issions\%20from\%20fuels.htm] (Accessed 11 November 2011).

Department of Energy and Climate Change (DECC). (2011). Carbon values used in DECC's energy modelling. [DECC]. Available at: [http://www.decc.gov.uk/assets/decc/11/cuttingemissions/carbon-valuation/3138-carbon-values-decc-energy-modelling.pdf] (Accessed 11 November 2011).

Drexhage J. and Murphy D. (2010). Sustainable Development: From Brundtland to Rio 2012. United Nations Headquaters: New York.

du Toit C. and van Tonder J. (2009). Africa's economic performance since 1994: can we do better?. In: Parsons R (ed), Zumanomics. Jacana Media: Auckland Park.

Edwards C. 2008. Social Cost-Benefit Analysis - the available evidence on drinking water. In: Pond K., Pedley S. and Edwards C. (2008). Valuing water - valuing well-being: a guide to understanding the costs and benefits of water interventions. [World Health Organization]. Available at: [http://www.who.int/water_sanitation_health/economic/cb_interventions/en/index.html] (Accessed 29 April 2011).

Environmental Protection Agency (EPA). (2005). Emission Facts: Average Carbon Dioxide Emissions Resulting from Gasoline and Diesel Fuel. [EPA]. Available at: [http://www.epa.gov/otaq/climate/420f05001.pdf] (Accessed 11 November 2011).

European Commission (EC). (2006). Guidance on the Methodology for Carrying out CostBenefit Analysis - Working document No. 4. European Commission Director General Regional Policy: Brussels.

Florio M., Maffii S., Atkinson K., de Rus G., Evans D., Ponti M., Genco M., Parolin R., Vignetti S., Bollati J., Giglio M., Panza G. and Sartori D. (2008). Guide to Cost Benefit Analysis of Investment Projects. European Commission: Brussels.

Franzese O., Knee H.E. and Slezak L. (2009). Effect of Tires on Class-8 Heavy Truck Fuel Efficiency. Center for Transportation Analysis: Knoxville.

Gregory K. (2011). FOS Response to Environment Canada's $\mathrm{CO}_{2}$ Emissions Reduction Plan. Friends of Science Society: Connaught.

Healey J. (2003). House of Commons - Environment, Food and Rural Affairs - Minutes of Evidence. [Parliament UK]. Available at: [http://www.publications.parliament.uk/pa/cm200203/cmselect/cmenvfru/929/3091706.htm] (Accessed 11 November 2011).

Khan K.A. and Khan A. (2009). Improved Bio-gas Plant - an Environmental Friendly Renewable Energy. Proceedings of World Academy of Science: Engineering \& Technology. 51: 468-473.

Legros G., Havet I., Bruce N. and Bonjour S. (2009). The Energy Access Situation in Developing Countries. World Health Organization: New York. 
Lowell D. and Balon T. (2009). Setting the Stage for Regulations of Heavy-Duty Vehicle Fuel Economy \& GHG Emission: Issues and Opportunities. M.J. Bradley \& Associates LLC: Concord.

Millikin M. (ed). (2009). Study Concludes That Class 8 Truck Fuel Consumption Could Be Reduced By Up to 50\% By 2017 Using Existing and Emerging Technologies; Current Payback Requirements Could Forestall Implementation. [Green Car Congress]. Available at: [http://www.greencarcongress.com/2009/11/icct-20091120.html] (Accessed 11 November 2011).

Mullins D, Mosaka D.D., Green A.B., Downing R. and Mapekula P.G. (2007). A Manual for Cost Benefit Analysis in South Africa with Specific Reference to Water Resource Development. WRC Report No.TT 305/07. Water research commission: Pretoria.

Pandey B.R., Partin J.G., Subedi P.S., Sharma M. and Dhakal S. (2005). Financing Biogas: A Reference manual for Microfinance Institutions in Nepal. Winrock International: Brussels.

Pearce D.W., Atkinson G. and Mourato S. (2006). Cost-Benefit Analysis and the Environment: Recent Developments. OECD: Paris.

Prüss-Üstün A. and Corvalán C. (2006). Preventing Disease Through Healthy Environments Towards an estimate of the environmental burden of disease. World Health Organization: Geneva.

Renwick M., Subedi P.S. and Hutton G. (2007). Biogas for better life: An African Initiative - A Cost-Benefit Analysis of National and Regional Integrated Biogas and Sanitation Programmes in Sub-Saharan Africa: Prepared for the Dutch Ministry of Foreign Affairs. Winrock International: Arkansas.

Sinha P., Depro B. and Braun F. (2010). Regulatory Impact Analysis (RIA) for Existing Stationary Compression Ignition Engines NESHAP. Environmental Protection Agency (EPA): Washington DC.

Smith M.T. (2011). The Financial and Economic Feasibility of Biodigester Use and Biogas Production for Rural Households. Master of Commerce Thesis, University of KwaZuluNatal, South Africa.

Sookraj A. (2002). The provision of services in rural areas -with special reference to health and education: A case study of Okhombe Village in the North-West Drakensberg, KwaZuluNatal. Master of Arts Thesis. University of KwaZulu-Natal South Africa.

Statistics South Africa (Stats SA). (1996). Okhahlamba [KZ235] Census 96. [StatsSA]. Available at: [www.statssa.gov.za/census01/Census96/Wards/catb/KZ235.htm] (Accessed 28 November 2010).

Statistics South Africa (Stats SA). (2011). Mineral accounts for South Africa 1980-2008 Discussion document - D0405.2. Statistics South Africa: Pretoria.

The Presidency: Republic of South Africa. (2009). Development Indicators. [The Presidency]. Available at: [http://www.thepresidency.gov.za/learning/me/indicators/2009/indicators.pdf] (Accessed 17 January 2011). 
United Nations Development Program (UNDP). (2013). Millennium Development Goals. [United Nations]. Available at: [http://www.undp.org/content/undp/en/home/mdgoverview.html] (Accessed 18 February 2013).

United Nations Economic Commission for Africa (UN- ECA). (2011). The Impacts of HIV/AIDS on Families and Communities in Africa. Economic Commission for Africa: Addis Ababa.

US Department of Energy. (2005). Fact \#372: Truck Fuel Economy by Size Class. [U.S. Department of Energy]. Available at: [http://www1.eere.energy.gov/vehiclesandfuels/facts/2005/fcvt_fotw372.html] (Accessed 11 November 2011).

World Bank. (1996). Staff Appraisal Report - Nepal - Rural Water Supply and Sanitation Project. World Bank Report No. 15232-NEP. The World Bank: Washington DC.

World Health Organization (WHO). (2004). Global Health Observatory Data Repository Environmental Health - Household Air Pollution. [WHO]. Available at: [http://apps.who.int/ghodata/?vid=61540] (Accessed 18 November 2011).

World Health Organization (WHO). (2007). Global Health Observatory Data Repository Environmental Health - Exposure - Households using solid cooking fuels. [WHO]. Available at: [http://apps.who.int/ghodata/?vid=61540] (Accessed 18 November 2011). 
Table 7. Valuation methodology and key assumptions.

Financial costs

\begin{tabular}{|c|c|c|c|}
\hline Item & Estimation method & Key assumptions & $\begin{array}{l}\text { Value per digester } \\
\text { (ZAR) }\end{array}$ \\
\hline 1. BiogasPro digester & Price obtained directly from supplier & $\begin{array}{l}\text { Biodigester model used for the } \\
\text { study is BiogasPro.Constant costs } \\
\text { (no economies of scale in } \\
\text { production). }\end{array}$ & 22743 \\
\hline $\begin{array}{l}\text { 2. Biodigester transportation } \\
\text { Cape Town-Pietermaritzburg- } \\
\text { Okhombe }\end{array}$ & $\begin{array}{l}\text { Provided by supplier (validated by } \\
\text { three higher quotations from } \\
\text { transport companies) }\end{array}$ & $\begin{array}{l}\text { Nine biodigesters at a time } \\
\text { transported on an } 18 \mathrm{~m} \text { heavy duty } \\
\text { vehicle (HDV) i.e. multiple (9) } \\
\text { installations on site. }\end{array}$ & 3147.67 \\
\hline \multicolumn{4}{|l|}{ 3. Installation cost } \\
\hline \multicolumn{4}{|l|}{ 3.1 Civil construction } \\
\hline Hole excavation & $\begin{array}{l}\text { Cost of labour: shadow wage } \\
\text { rate[Minimum wage for farm } \\
\text { workers x estimated time based on } \\
\text { previous installations.] }\end{array}$ & $\begin{array}{l}\text { Community members dig and } \\
\text { prepare own holes. }\end{array}$ & 821.36 \\
\hline Backfill & $\begin{array}{l}\text { Cost estimates provided by RenEn, } \\
\text { the only accredited installer in KZN }\end{array}$ & $\begin{array}{l}\text { Nine installations over one week; } \\
\text { two digesters filled per day. }\end{array}$ & 3363.32 \\
\hline Plumbing & $\begin{array}{l}\text { Biodigester installed } 18 \mathrm{~m} \text { from } \\
\text { house. }\end{array}$ & & 1869.39 \\
\hline Transport (service providers) & $\begin{array}{l}\text { Travel cost from Pietermaritzburg to } \\
\text { Okhombe return }\end{array}$ & $\begin{array}{l}\text { Nine installations over one week; } \\
\text { technical staff on site. }\end{array}$ & 149.34 \\
\hline Accommodation & $\begin{array}{l}\text { Average cost of nearby } \\
\text { accommodation }\end{array}$ & $\begin{array}{l}\text { Four nights' accommodation for } \\
\text { technical staff. }\end{array}$ & 222.22 \\
\hline \multicolumn{4}{|l|}{ 3.2 Gas installation } \\
\hline Ground preparation & $\begin{array}{l}\text { Cost estimates provided by RenEn, } \\
\text { the only accredited installer in KZN }\end{array}$ & $\begin{array}{l}\text { Biodigester installed } 18 \mathrm{~m} \text { from } \\
\text { house. }\end{array}$ & 386.97 \\
\hline Plumbing & & & 3787.4 \\
\hline Transport (service providers) & $\begin{array}{l}\text { Travel cost from Pietermaritzburg to } \\
\text { Okhombe return }\end{array}$ & $\begin{array}{l}\text { Nine installations over one week; } \\
\text { technical staff on site. }\end{array}$ & 149.34 \\
\hline
\end{tabular}


Accommodation

Total installation costs

4. Cost of biodigester-utilisin gas burner

5. Repair \& maintenance costs

6. Training and technical assistance

Total financial costs
Average cost of nearby accommodation
Four nights' accommodation for technical staff.

Price obtained directly from supplier Includes transport and taxes.

0
Obtained directly from supplier who expects these costs to be zero Estimated by supplier, who provides training
Users abide by general guidelines

of use as per training.

Local resident will provide training

to representatives of user

households at installation, 3

months, 6 months and 12 months

(one day each); multiple (9)

installations.

All financial costs are incurred in year 1 , therefore not subject to discounting

Financial benefits

\begin{tabular}{|c|c|c|c|}
\hline Item & Estimation method & Key assumptions & $\begin{array}{l}\text { Value per digester } \\
\text { (ZAR) }\end{array}$ \\
\hline 1. Avoided fuel costs & $\begin{array}{l}\text { Market prices of estimated fuel } \\
\text { savings. [Fuel expenditure } \\
\text { breakdown obtained from } \\
\text { household survey; cooking fuel } \\
\text { savings per firewood, LPG, paraffin, } \\
\text { electricity calculated as proportion } \\
\text { of each fuel type used for cooking x } \\
\text { market price }\end{array}$ & $\begin{array}{l}\text { Biogas will replace all other } \\
\text { cooking fuels in households where } \\
\text { a biodigester is installed }\end{array}$ & 180.57 per month \\
\hline 2. Avoided fertiliser costs & $\begin{array}{l}\text { Market price of fertiliser.[Fertiliser } \\
\text { use and costs obtained from } \\
\text { household survey.] }\end{array}$ & $\begin{array}{l}\text { Bioslurry will replace all purchased } \\
\text { fertiliser in households where a } \\
\text { biodigester is installed }\end{array}$ & 30.82 per month \\
\hline
\end{tabular}


3. Avoided medical expenditure
Health-related expenditure savings due to reduced indoor air pollution as a result of switching to biogas drawn from Ugandan study Pandey et al. (2007), Renwick et al. (2007)
4. Financial value of saved lives Avoided funeral costs[Indoor air pollution (IAP) related deaths in the study area extrapolated from $\mathrm{WHO}$ data - reduction proportionate to reduced solid fuel use $\rightarrow$ valued using local data for average cost of funeral.]
Total financial benefits (PV)

\section{Economic costs}

Item

\section{Estimation method}

Value per digester

1. Social costs of biodigester

Social cost of carbon

transport Cape Town-Okhombe emissions. [Applied to estimated

carbon emissions based on

expected fuel use of delivery vehicle.]
Biogas will reduce indoor air pollution by $65 \%$, on the basis that biogas use reduces firewood consumption by $65 \%$

$65 \%$ reduction in IAP related deaths 4.95 per year as a result of replacing solid fuels with biogas. Funeral cost: one third of the average, annual household income for the study area (UN-ECA 2011:18).

On-going flows of benefits are considered over a 15 year period.Discounted at $6 \%$

Key assumptions

Limited to external cost of $\mathrm{CO} 2$

(ZAR)

165.54 per year

emissions. Nine biodigesters

transported on an $18 \mathrm{~m}$ heavy duty

vehicle (HDV). Round trip Cape

Town â€" Pietermaritzburg â€"

Okhombe 3534 kmAverage HDV

$\mathrm{CO} 2$ emission $2651 \mathrm{~g} /$ litre of fuel.

Social cost of carbon (ZAR

180.81/tonne of CO2) See Section

2.3.1.
61.2 
2. Time spent feeding biodigester

Total economic costs (PV)

Economic benefits

Item

with biogas instead of

traditional fuels

Reduced firewood collection

time

Reduced cooking \& utensilcleaning time

2. Improved health
Value of time: weighted min wage.[Time required to collect \& mix necessary water $\&$ dung estimated from household survey, \& experienced rural biogas practitioner $\rightarrow$ time valued as explained in Section 2.3.2.1 as average min wage for unskilled labour in SA, weighted according to likely time use as derived from household survey.]
Estimation method
Value of time by

activity:Productive economic

activity valued at $100 \%$ of unskilled

labour wage rate (we)Household

activity valued at $50 \%$ of unskilled labour wage rate (wh)Other activity

(including leisure and socialising) valued at $25 \%$ of unskilled labour wage rate(wo).Considered over a 15 year period.Discounted at $6 \%$

Key assumptions

Value per digester

(ZAR)

wage. [Expected reduction in

reported wood collection time

(from survey) $\rightarrow$ valued according to

principles in Section 2.3.2.1.]

Value of time: weighted min

Affects only households using traditional fuels (firewood, cow dung) before switching to

biogas. Wood for cooking accounts for $65 \%$ of wood collected.Value of time - see above

Daily average saving of 134 mins wage.[Expected time savings drawn due to switch to biogas.Value of from other comparable studies (Renwick et al. 2007) \& valued as above.]
132.21 per month

186.52 per month 
Health-related productivity gains

Saved lives

3. Local environmental benefits:Preservation of indigenous treesReduction of erosion

4. Greenhouse gas \& $\mathrm{CO} 2$ reduction

Total economic benefits (PV)
Value of time: weighted min wage.[Incidence of acute lower respiratory infections (ALRI) (data for Sub-Saharan Africa, WHO 2004) proportion due to IAP from solid fuel (Prüss-Üstün and Corvalán 2006) $\rightarrow$ number affected in study population $\rightarrow X$ average number of days incapacitation due to ALRI $\rightarrow$ proportionate reduction in

incidence \& days lost due to switch to biogas $\rightarrow$ time valued as explained above.]

Value of a statistical/economic life.[IAP related deaths in study area extrapolated from $\mathrm{WHO}$ data $\rightarrow$ reduction proportionate to reduced solid fuel use $\rightarrow$ valued as a statistical life as explained in Section 2.3.2.3.]

Not quantified

Not quantified
Focus on ALRI (the most prevalent IAP-related disease).Incidence of

IAP-related ALRI \& resultant

incapacitation in Okhombe is comparable to that in source studies used.Switch to biogas reduces both solid fuel use and IAPinduced incapacitation by $65 \%$.Time valued as above

$65 \%$ reduction in IAP related deaths 16331.21 per year as a result of replacing solid fuels with biogas.Value of a statistical life (VOSL) adjusted to study context as explained in Section 2.3.2.3, to $\$ 2$ million (adjusted to 2011 ZAR)

On-going flows of benefits are considered over a 15 year period.Discounted at $6 \%$ 